\title{
Gender perspectives on knowledge and practices regarding tuberculosis in urban and rural areas in Pakistan
}

M. Agboatwalla, ${ }^{1}$ G.N. Kazi, ${ }^{2}$ S.K. Shah ${ }^{3}$ and M. Tariq ${ }^{1}$

$$
\begin{aligned}
& \text { خصائص الجنسين من حيث المعارف والممارسات المتعلقة بالسل في المناطق الحضضرية والريفية في } \\
& \text { باكستان } \\
& \text { موبينا اججبواتوالا، جو لام نابي كازي، سيد قرم شاه، ماريا طارق }
\end{aligned}
$$

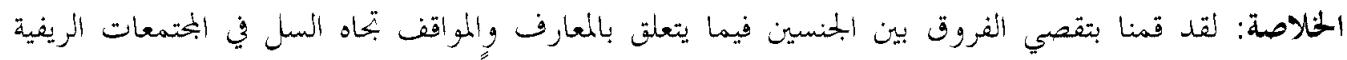

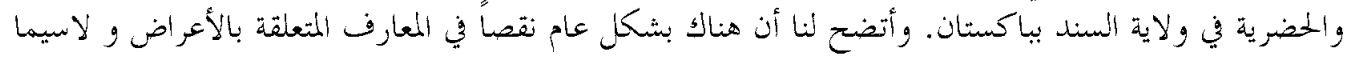

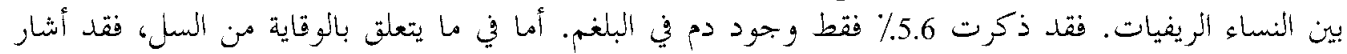

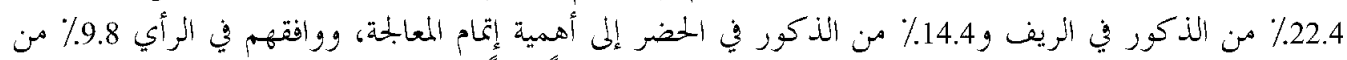

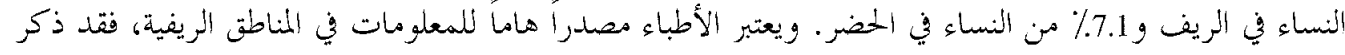

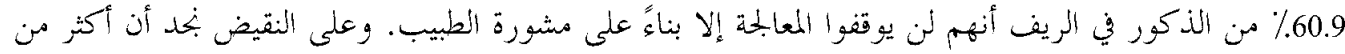

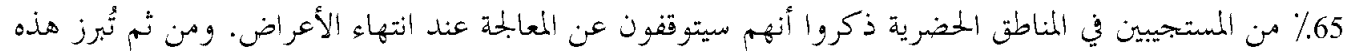

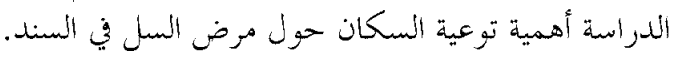

ABSTRACT We investigated gender differences in knowledge of and attitude towards tuberculosis (TB) in urban and rural communities in Sindh province, Pakistan. Knowledge of symptoms was generally deficient, particularly in rural females. Regarding TB prevention, $22.4 \%$ of rural and $14.4 \%$ of urban males said completing treatment was important; only $9.8 \%$ of rural and $7.1 \%$ of urban females agreed. Doctors were an important source of information in rural areas and $60.9 \%$ of rural males said they would only stop treatment on a doctor's advice. In contrast, $>65 \%$ of respondents in urban areas said they would stop treatment when symptoms ended. Our study highlights the need to increase population awareness about TB in Sindh.

\begin{abstract}
Sexospécificités dans les connaissances et les pratiques concernant la tuberculose en milieu urbain et rural au Pakistan

RESUME Nous avons examiné les différences selon les sexes dans les connaissances et les attitudes concernant la tuberculose dans des communautés urbaines et rurales de la province du Sindh (Pakistan). La connaissance des symptômes était faible de manière générale, notamment chez les femmes rurales. En ce qui concerne la prévention de la tuberculose, $22,4 \%$ des hommes ruraux et $14,4 \%$ des hommes urbains ont déclaré que le fait de suivre le traitement jusqu'au bout était important ; seulement $9,8 \%$ des femmes rurales et $7,1 \%$ des femmes urbaines en convenaient. Les médecins représentaient une source d'information importante dans les zones rurales et $60,9 \%$ des hommes ruraux ont déclaré qu'ils n'interrompraient le traitement que sur avis d'un médecin. Par contre, plus de $65 \%$ des répondants en milieu urbain ont déclaré qu'ils interrompraient le traitement à l'arrêt des symptômes. Notre étude souligne la nécessité de sensibiliser la population de la province du Sindh à la tuberculose.
\end{abstract}

${ }^{1}$ Health Oriented Preventive Education (HOPE), Karachi, Pakistan.

${ }^{2}$ World Health Organization, Sindh, Pakistan.

${ }^{3}$ TB Control Programme, Pakistan.

المجلة الصحية لشرق المتوسط، منظمة الصحة العالمية، المجلد التاسع، العدد ع، ب... 


\section{Introduction}

Tuberculosis (TB) is one of the most important infectious causes of mortality in the developing world. Estimated annual global incidence is 8 million cases and there are 2 million deaths yearly $[1,2]$. The total number of TB cases is predicted to increase in all regions up to 2005, with the expected increase $3 \%$ per year on average. Pakistan has the 6th highest TB burden globally and accounts for $44 \%$ of the TB burden in the WHO Eastern Mediterranean Region [2]. It is currently estimated that there are around 1.5 million TB patients in Pakistan, while every year 250000 people develop the disease [3]. In Sindh province, 88000 persons get this disease every year, including 44000 smear-positive cases $[3,4]$.

Tuberculosis kills more women than all causes of maternal mortality combined [5]. In 1998, about three-quarters of a million women died from TB and over 3 million contracted the disease, accounting for about 17 million disability adjusted life years [6]. A number of studies have shown that in high prevalence countries women in their reproductive years (15-40 years) have higher rates of progression to disease than men of the same age. This may be related to the physiological changes associated with reproduction [7-9]. As TB affects women mainly in their economically and reproductively active years, the disease has a severe impact on their children and families [10]. Women also face obstacles to gaining access to diagnostic facilities, investigation of the disease and completing treatment. In addition, the added burden of housework, childcare and employment allows them very little time to access health care and TB care for themselves [10-12].

Gender, culture and personal experience are generally said to influence healthseeking behaviour. Several authors agree that the human element in TB control has often been overlooked and suggest that there would be significantly better control if more attention were given to the health culture of the population [13-15]. Local surveys on knowledge and attitude towards TB greatly benefit the planning, health education and implementation of TB control programmes. Research has shown that several health interventions have failed because they were designed without ascertaining any knowledge of the health behaviour of the target population [16]. For successful TB control, it is important to target women and to elicit the beliefs and knowledge of women regarding TB as well as their health-seeking behaviour.

To help in the baseline assessment of the differences in knowledge about TB in males and females, we conducted a study in urban and rural areas of Sindh province in Pakistan with the following objectives: to study the differences in knowledge of cause, spread and treatment of TB; to compare male and female health-seeking behaviours; and to compare urban and rural perspectives regarding knowledge of and attitude towards TB.

\section{Methods}

This was a cross-sectional, descriptive study. The study was conducted in 1 urban site in Karachi known as Baldia Town and 1 rural site in Hyderabad division known as Tando Jam. Two hundred households (100 urban and 100 rural) were selected from the data-base of voters using a table of random numbers. All family members 20-45 years were included in the study. The questionnaire was given to every adult male and female between 20 and 45 years of age living permanently in these households. Anyone who had been staying for less than 6

المجلة الصحية لشرق المتوسط، منظمة الصحة العالمية، المجلد التاسع، العدد ع، ب... 
months was not interviewed. In the urban area, 455 individuals (229 males and 226 females) were interviewed, while in the rural area 299 individuals (156 males and 143 females) were interviewed, giving a total of 754. The mean number of persons per household in the urban area was 9.6, while in the rural area it was 8.4. Consent was obtained from the respondents before administering the questionnaire and there were no refusals.

Data were collected using semistructured questionnaires having both closed and open-ended questions. Questionnaires were translated into the national language, Urdu, and the local language, Sindhi. The household questionnaire included questions on age, sex, literacy and socioeconomic status of the respondents. The individual questionnaires contained questions regarding knowledge of $\mathrm{TB}$, including causes and factors responsible for its spread, signs and symptoms of TB, parts of the body affected, investigations needed in such cases, reasons for stopping treatment and sources of information. Health-seeking behaviour was also determined for both males and females.

Open-ended questions were asked concerning the individual's attitude towards TB and the sociocultural stigmas associated with the disease. The community's attitude towards females who develop TB was also elicited. The questionnaire was administered by interviewers who underwent a 2day training on questionnaire administration techniques. In the case of male respondents, a male interviewer was used and for females, a female interviewer. The entire questionnaire was completed in $40 \mathrm{~min}-$ utes. The raw data from open-ended questions was categorized into open codes. These open codes were applied by 2 independent researchers and the results were discussed with the whole team. $P$-values were calculated using chi-squared.

\section{Results}

Of the 754 people interviewed, 385 were male, $62 \%$ of them married, and 369 were female, $74.3 \%$ of whom were married. The greatest proportion of the households (42\% in urban and $43 \%$ in rural areas) had an income of 2000-5000 Pakistan rupees per month (US\$ 33-83). Radio and television ownership varied from $50 \%$ to $70 \%$ in urban areas and $45 \%$ to $65 \%$ in rural areas. Nearly $78 \%$ of women in rural areas were illiterate compared with $51 \%$ in urban areas. Male literacy was higher, urban $88 \%$ and rural $45 \%$.

Observations were made regarding the symptoms of TB as perceived by males and females. In the urban area, cough was the most commonly cited symptom for both males (67.2\%) and females (76.5\%). Blood in sputum was again cited by both males (17.9\%) and females (18.6\%). Prolonged fever was most commonly reported by females (29.6\%). Anorexia and night sweats were not reported by either males or females. In the rural area, a significant difference was seen between male and female perceptions of symptoms; $57.7 \%$ of males cited cough as a predominant symptom compared to $21 \%$ of females. Again, $25.6 \%$ of males gave blood in sputum as an important symptom compared with only $5.6 \%$ of females. Prolonged fever was cited by $19.2 \%$ of males but only $4.9 \%$ of females. Neither males nor females reported night sweats, anorexia or weight loss as symptoms before probing (Table 1).

Very few people were aware of the causative agent of TB, especially rural females. In the urban area $30 \%$ of males and 
Table 1 Male and female (urban and rural) perceptions regarding symptoms of TB

\begin{tabular}{|c|c|c|c|c|c|c|}
\hline \multirow[t]{2}{*}{ Symptom } & \multicolumn{3}{|c|}{ Urban } & \multicolumn{3}{|c|}{ Rural } \\
\hline & $\begin{array}{c}\text { Male } \\
\%\end{array}$ & $\begin{array}{c}\text { Female } \\
\%\end{array}$ & $P$-value & $\begin{array}{c}\text { Male } \\
\%\end{array}$ & $\begin{array}{c}\text { Female } \\
\%\end{array}$ & $P$-value \\
\hline Cough & 67.2 & 76.5 & $>0.05$ & 57.7 & 21 & $<0.001$ \\
\hline Blood in sputum & 17.9 & 18.6 & $>0.05$ & 25.6 & 5.6 & $<0.001$ \\
\hline Weight loss & 7.9 & 8.8 & $>0.05$ & 4.5 & 1.4 & $>0.05$ \\
\hline Prolonged fever & 7.4 & 29.6 & $<0.01$ & 19.2 & 4.9 & $<0.0001$ \\
\hline Persistent cough & 7.0 & 0.4 & $<0.05$ & 1.3 & 0 & $<0.0004$ \\
\hline Anorexia & 0.4 & 1.3 & $>0.05$ & 3.8 & 1.4 & $>0.05$ \\
\hline Night sweats & 0 & 0 & - & 0 & 0 & - \\
\hline Other & 1.3 & 8.0 & $>0.05$ & 1.3 & 0 & - \\
\hline
\end{tabular}

$35 \%$ of females cited "germs" as causing $\mathrm{TB}$, while in the rural areas $18.6 \%$ of males and $9.8 \%$ of females mentioned "germs". $\mathrm{X}$-ray as a diagnostic test for TB was indicated by nearly $51 \%$ of males and females in the urban area, $69 \%$ of males in the rural area and $30 \%$ of rural females. Sputum testing, however, was not well known, with only $24 \%$ of urban males, $28.8 \%$ urban females, $23.1 \%$ of rural males and only $6.3 \%$ of rural females being aware of it.

We investigated the knowledge of the participants regarding spread of TB (Table 2 ). In the rural area, $37.2 \%$ of males and $24.5 \%$ of females said that TB is spread by droplets while in the urban area this was cited by $38.9 \%$ of males and $28.8 \%$ of females. Spitting as a means of spreading TB was given by $29.5 \%$ of males and only $4.2 \%$ of females in the rural area. In the urban area, only $9.2 \%$ of males and $11.5 \%$ of females said that TB is spread by spitting. More rural males $(22.4 \%)$ than females $(6.3 \%)$ said that using the same eating utensils as a TB patient can facilitate the spread of TB. In the urban area, 14.2\% of females and $3.1 \%$ of males felt the same. Other reasons for the spread of TB includ- ed drinking dirty water, reusing syringes and sexual relations (Table 2).

Regarding protective measures against $\mathrm{TB}$, there were significance differences between urban and rural groups (Table 3). In the urban area knowledge about bacille Calmette-Guérin (BCG) was negligible in males, $1.7 \%$ compared to $32.7 \%$ in rural males. About a quarter of all respondents said that staying away from a TB patient was the best protective measure; while in men the difference between the urban and

Table 2 Male and female (urban and rural) perceptions on how TB is spread

\begin{tabular}{lrrrr}
\hline Spread of TB & \multicolumn{2}{c}{ Urban } & \multicolumn{2}{c}{ Rural } \\
& $\begin{array}{r}\text { Male } \\
\text { \% }\end{array}$ & $\begin{array}{c}\text { Female } \\
\text { \% }\end{array}$ & $\begin{array}{c}\text { Male } \\
\text { \% }\end{array}$ & $\begin{array}{c}\text { Female } \\
\%\end{array}$ \\
\hline Droplet & 38.9 & 28.8 & 37.2 & 24.5 \\
Spitting & 9.2 & 11.5 & 29.5 & 4.2 \\
Utensils & 0.9 & 0.9 & 22.4 & 6.3 \\
Dirty water & 2.6 & 4.9 & 3.2 & 0.7 \\
Sexual relations & 3.1 & 14.2 & 1.3 & 0.7 \\
Syringes & 0.4 & \multicolumn{1}{c}{0} & 7.7 & 2.1 \\
\hline
\end{tabular}

المجلة الصحية لشرق المتوسط، منظمة الصحة العالمية، المجلد التاسع، العدد ع، ب... 


\begin{tabular}{|c|c|c|c|c|c|c|}
\hline \multicolumn{7}{|c|}{$\begin{array}{l}\text { Table } 3 \text { Male and female (urban and rural) perceptions on protective } \\
\text { measures against tuberculosis (TB) }\end{array}$} \\
\hline $\begin{array}{l}\text { Measures to protect } \\
\text { against TB }\end{array}$ & $\begin{array}{l}\text { Urban } \\
\%\end{array}$ & $\begin{array}{c}\text { Male } \\
\text { Rural } \\
\%\end{array}$ & $P$-value & $\begin{array}{l}\text { Urban } \\
\%\end{array}$ & $\begin{array}{c}\text { Female } \\
\text { Rural } \\
\%\end{array}$ & $P$-value \\
\hline Stay away from patient & 27.9 & 22.4 & 0.002 & 23.9 & 25.2 & 0.6 \\
\hline $\begin{array}{l}\text { Complete treatment } \\
\text { at home }\end{array}$ & 14.4 & 22.4 & $<0.0001$ & 7.1 & 9.8 & $<0.0001$ \\
\hline Use anti-TB drugs & 6.1 & 4.5 & $<0.0001$ & 10.6 & 0.7 & $<0.0001$ \\
\hline $\begin{array}{l}\text { Have separate utensils } f \\
\text { TB patient }\end{array}$ & or 5.7 & 8.3 & $<0.0001$ & 13.7 & 2.1 & $<0.0001$ \\
\hline Use boiled water & 3.5 & 3.2 & $<0.0001$ & 3.5 & 0 & $<0.0001$ \\
\hline bacille Calmette-Guérin & 1.7 & 32.7 & $<0.0001$ & 4.9 & 8.4 & 0.0002 \\
\hline Other & 0.4 & 0.6 & - & 1.6 & 0.7 & - \\
\hline
\end{tabular}

rural areas was significant $(P=0.002)$, it was not so for women $(P=0.6)$. Only $7.1 \%$ of the urban females said that completion of treatment at home was the best protective measure. This figure was $22.4 \%$ for rural males (Table 3)

Urban-rural disparity was evident in gauging knowledge as to which part of the body TB affects (Table 4). More urban males (39.9\%) than rural males (26.9\%) said the lungs were involved. Some men, $59.8 \%$ urban and $45.5 \%$ rural, said that TB affects the chest. Urban females were more knowledgeable than rural; $47.8 \%$ said that lungs were involved compared with only $13.3 \%$ of rural females. Around $41.2 \%$ of females in the urban area said the chest was involved compared with $19.6 \%$ in the rural area $(P<0.05)$. In both areas, neither males nor females were aware that kidneys, bones, the digestive system and the reproductive system could also be affected.

In the urban area, $81.4 \%$ of females preferred to go to a private clinic for treatment of minor illnesses compared to $21.7 \%$ of rural females. The majority of the rural females (62.9\%) preferred to visit the tertiary care hospital compared to only $13.3 \%$ of urban females $(P<0.05)$. In males, a similar pattern was seen with $84.7 \%$ of ur-

Table 4 Male and female (urban and rural) perceptions regarding which part of the body tuberculosis affects

\begin{tabular}{lcccc}
\hline $\begin{array}{l}\text { Body part } \\
\text { affected }\end{array}$ & \multicolumn{2}{c}{ Male } & \multicolumn{2}{c}{ Female } \\
& $\%$ & $\%$ & $\begin{array}{c}\text { Rurbal } \\
\text { Urban }\end{array}$ & $\begin{array}{c}\text { Rural } \\
\%\end{array}$ \\
\hline Chest & 59.8 & 45.5 & 41.2 & 19.6 \\
Lungs & 39.9 & 26.9 & 47.8 & 13.3 \\
Kidney & 10.5 & 0 & 12.8 & 3.5 \\
Digestive system & 2.6 & 2.6 & 8.8 & 2.1 \\
Anywhere & 2.6 & 6.4 & 31.7 & 4.2 \\
Neck & 1.3 & 0.6 & 0 & 2.1 \\
Bones & 0.4 & 0 & 3.1 & 2.1 \\
Skin & 0.4 & 10.9 & 0 & 3.5 \\
Ribs & 0.4 & 1.3 & 2.1 & 11.9 \\
Reproductive & & & & \\
$\quad$ organs & 0 & 0 & 0 & 0 \\
Liver & 0 & 0.6 & 0 & 1.4 \\
\hline
\end{tabular}


ban males preferring to go to a private clinic compared with only $39.7 \%$ of rural males. The most favoured type of health facility for rural males was the tertiary care hospital (50.6\%). Rural males also went to the hakim (traditional healer) and homeopath more often than women (rural and urban) and urban males (Table 5).

When asked about stopping treatment, the majority of urban respondents (> 65\%), males and females, said that they would stop treatment when the symptoms ended. This view was also expressed by $43.4 \%$ of rural females but only $32.1 \%$ of rural males. In rural males, $60.9 \%$ said they would follow the advice of the doctor on when to stop the treatment but in the urban areas $<25 \%$ of the respondents emphasized the role of the doctor in this respect. A very small percentage said they would stop treatment if they could not afford it (Table 6).

When asked with whom they would visit the health facility, only $28.7 \%$ of rural females said they would go alone while $53.0 \%$ said they would go with their husband or a family member (35.0\%). The

\begin{tabular}{lcccc}
\hline $\begin{array}{l}\text { Table } 5 \text { Male and female (urban and rural) } \\
\text { health-seeking behaviour }\end{array}$ \\
\hline Health facility & $\begin{array}{c}\text { Urban areas } \\
\text { Male } \\
\%\end{array}$ & $\begin{array}{c}\text { Female } \\
\%\end{array}$ & $\begin{array}{c}\text { Rural areas } \\
\text { Male } \\
\text { \% }\end{array}$ & $\begin{array}{c}\text { Female } \\
\%\end{array}$ \\
\hline Private clinic & 84.7 & 81.4 & 39.7 & 21.7 \\
Tertiary hospital & 7.9 & 13.3 & 50.6 & 62.9 \\
$\begin{array}{l}\text { Government } \\
\quad \text { dispensary }\end{array}$ & 3.9 & 4.0 & 10.9 & 21.0 \\
Hakim & & & & \\
Homeopathic & 0.9 & 0.4 & 0.6 & 0.7 \\
NGO clinic & 0 & 0.9 & 0.6 & 0 \\
\hline
\end{tabular}

Traditional healer.

NGO = nongovernmental organization .
Table 6 Male and female perceptions (urban and rural) about when to stop antituberculosis treatment

\begin{tabular}{|c|c|c|c|c|}
\hline \multirow{2}{*}{$\begin{array}{l}\text { When to stop } \\
\text { treatment }\end{array}$} & \multicolumn{2}{|c|}{ Male } & \multicolumn{2}{|c|}{ Female } \\
\hline & $\begin{array}{c}\text { Urban } \\
\%\end{array}$ & $\begin{array}{c}\text { Rural } \\
\%\end{array}$ & $\begin{array}{c}\text { Urban } \\
\%\end{array}$ & $\begin{array}{l}\text { Rural } \\
\%\end{array}$ \\
\hline $\begin{array}{l}\text { When symptoms } \\
\text { end }\end{array}$ & 65.5 & 32.1 & 66.8 & 43.4 \\
\hline $\begin{array}{l}\text { When doctor } \\
\text { advises }\end{array}$ & 23.6 & 60.9 & 23.0 & 21.0 \\
\hline Cannot afford it & 0 & 1.9 & 1.3 & 0.7 \\
\hline
\end{tabular}

majority $(72.0 \%)$ of rural males said they would go alone. In the urban area, only $35.8 \%$ of females were willing to go alone but $33.6 \%$ said that they would need to be with their husband while 55\% said they could be accompanied by any family member. A majority of the urban males (77\%) also said that they would go to the health facility alone.

To ascertain if it would be possible to get to hospital to get treatment for TB on a regular basis, nearly $30.5 \%$ of urban females said that they would not be able to go to the hospital, while $90 \%$ of males said they would go. In the rural areas, $65 \%$ of males said that they would be willing to go to the hospital to get treatment, while $70 \%$ of females did not agree to go to the hospital to get treatment. Only $27 \%$ of males and $38 \%$ of females in the urban area said that they would allow an outsider to come and give the medicine to a TB patient. Of these, half said that only a doctor could come, while nearly a quarter said that only a female could come. In contrast, in the rural area nearly $63 \%$ of males and $86 \%$ of females said that an outsider could come and provide the TB medicines. However, $80 \%$ of them said it should be a doctor or a woman.

المجلة الصحية لشرق المتوسط، منظمة الصحة العالمية، المجلد التاسع، العدد ع، ب...T 
Only $12 \%-14 \%$ of the respondents (except rural males, $34.8 \%$ ) had received information about TB from either the radio or television (Table 7). About 15\% of men, both urban and rural, had received information from newspapers. Very few rural women $(3.5 \%)$ received any knowledge about TB from newspapers. However, $66.0 \%$ of rural men acquired knowledge about TB from their local doctor, compared with $31.0 \%$ of urban men. Friends were also an important source of information in urban areas (Table 7).

\section{Discussion}

Overall knowledge regarding TB has been found to be extremely deficient in both sexes, but especially in rural females. The respondents' perceptions about the disease indicate the sociocultural trends prevalent in society as well as lack of correct information on the disease. Several important trends regarding basic knowledge as well as the social perceptions pertaining to gender differences and urban-rural disparity have been highlighted through this study.

\begin{tabular}{|c|c|c|c|c|}
\hline \multicolumn{5}{|c|}{$\begin{array}{l}\text { Table } 7 \text { Sources of information on } \\
\text { tuberculosis (TB) stated by males and } \\
\text { females in urban and rural areas }\end{array}$} \\
\hline $\begin{array}{l}\text { Source of } \\
\text { information }\end{array}$ & $\begin{array}{l}\text { Urban } \\
\%\end{array}$ & $\begin{array}{l}\text { lale } \\
\text { Rural } \\
\%\end{array}$ & $\begin{array}{c}\text { Fem } \\
\text { Urban } \\
\%\end{array}$ & $\begin{array}{l}\text { nale } \\
\text { Rural } \\
\%\end{array}$ \\
\hline Doctor & 31.0 & 66.0 & 12.8 & 25.9 \\
\hline Friends & 27.5 & 3.8 & 16.8 & 1.4 \\
\hline Newspaper & 15.3 & 14.7 & 12.8 & 3.5 \\
\hline Radio/television & 14.8 & 34.6 & 14.6 & 11.9 \\
\hline TB patient & 6.1 & 1.3 & 15.9 & 1.4 \\
\hline School & 1.7 & 0 & 0.9 & 0 \\
\hline $\begin{array}{l}\text { Leader/religious } \\
\text { man }\end{array}$ & 0 & 0 & 0 & 0.7 \\
\hline
\end{tabular}

The perceived causes of TB varied from "germs" to dirty water, many respondents, however, also associated TB with drug addiction, which is an interesting observation. Smoking and alcohol consumption have also be cited in several other studies conducted in Kenya, Philippines and Bombay [17-19]. Rural males were more concerned about the sharing of utensils than rural females. Most respondents were aware that TB is a contagious disease and "sharing with a TB" patient was considered a major factor in its spread. This finding is supported in studies from Kenya and India $[17,19]$.

Knowledge about BCG vaccination as a preventive measure was very limited, except in rural men (32.7\%). Again, a substantial proportion of rural men (22.4\%) and some urban men (14.4\%) said that completing the treatment helped in preventing others from developing TB. Rural females generally had less knowledge on means of protection against TB than the other 3 groups.

The disparity in health-seeking behaviour between the urban and rural population was quite apparent in this study; the urban respondents generally frequented private clinics while the rural respondents, especially males, visited government public hospitals more frequently. Females were found to be more likely to discuss their medical problems with their husbands or other family members while the males were found to chiefly discuss these issues with their doctors. It was seen that rural males followed the advice of the doctor regarding when anti-TB treatment should be stopped. This health-seeking behaviour explains the better knowledge level of the rural males. Doctors appear to play a limited role in providing health education in urban areas. In the urban area, males and females frequently visit private practitioners and in slum ar-

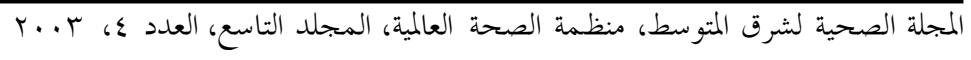


eas, many private practitioners are unqualified health care providers. Even if qualified, they do not participate in continuing medical education programmes and are unaware of the recent trends in disease and they do not have time to give health education messages to their patients. Since public health programmes such as directly observed treatment short-course (DOTS) are not implemented through the private system, many are not even aware of these strategies. Hence, in the urban areas, knowledge of males as well as females was limited.

In the rural areas, most public health strategies are implemented at the public health facilities, where the doctors are well versed in the public health programmes and provide health education messages to all patients. Since rural males visit these public health facilities, they have a better perception of the disease and are more knowledgeable about various issues pertaining to TB. Rural females are not allowed to venture out of the house freely, hence their exposure is limited, and not only do they have a narrow vision of the disease implications, their understanding and perception of the disease are also very limited. They tend to view TB as a "punishment from God" and strongly stigmatize the disease. These observations are further strengthened by the finding that the media (radio, television, newspapers) were not an important source of information on TB except for rural males. This is a manifestation of groups of rural men watching television in hotels in villages. In the case of rural males (66\%), the doctor plays an important part in im- parting knowledge. Hence, contrary to the general belief, it was the rural males who were more aware of the disease implications of TB.

The DOTS strategy is the recommended treatment for TB in Pakistan. This strategy involves supervised administration of TB drugs and may require daily visits of the TB patient to a health facility for administration of the drug or supervised drug administration at home in the presence of the health worker. We found that both rural and urban females were generally reluctant to visit health facilities alone, more so rural females. Rural women would not be allowed to visit the health facility unless accompanied by husbands or other family members. Rural respondents were, however, more open to allowing outsiders to come to the house to provide medicines.

Health-related beliefs and practices play a very important role in the success of any health intervention strategy. For the success of DOTS in Pakistan, it is important ascertain the willingness of the patients to take the TB medicines in the presence of health personnel. Our study outlines the constraints that females, especially rural females, may face in regular visits to the health facility. The urban restraint, i.e. unwillingness to allow outsiders into the house, should also be taken into consideration. Female health workers, either lady health workers or female community workers, could be employed in this capacity. However, this would need to be strengthened by forceful motivation from the Government.

\section{References}

1. Dye C, Scheele S, Dolin P. Consensus statement. Global burden of tuberculosis: estimated incidence, prevalence and mortality by country. WHO global surveillance and monitoring project. Journal of the American Medical Association, 1999, 282:677-86.

المجلة الصحية لشرق المتوسط، منظمة الصحة العالمية، المجلد التاسع، العدد ع، ب...T 
2. Global tuberculosis control. Geneva, World Health Organization, 2001 (WHO/ CDS/TB/2001.287).

3. Global tuberculosis control, surveillance, planning, financing. Geneva, World Health Organization, 2002 (WHO/ CDS/TB/2002.295).

4. National guidelines for tuberculosis control in Pakistan. Islamabad, Federal Ministry of Health, 1999 (NTP.MOH. GOP).

5. World Bank. World development report 1993: investing in health. New York, Oxford University Press, 1993.

6. Global tuberculosis control. Geneva, World Health Organization, 1999 (WHO/ CDS/CPC/TB/99.259).

7. Connolly M, Nunn P. Women and tuberculosis. World health statistics quarterly, 1996, 49:115-9.

8. Comstock GW, Livesay VT, Woolpert SE. The prognosis of a positive tuberculin reaction in childhood and adolescence. American journal of epidemiology, 1974, 99(2):131-8.

9. Holmes CB, Hausler H, Nunn P. A review of sex differences in the epidemiology of tuberculosis. International journal of tuberculosis and lung disease, 1998, 2(2): 96-104.

10. Uplekar MW et al. Attention to gender issues in tuberculosis control. International journal of tuberculosis and lung disease, 2001, 5(3):220-4.

11. Rajeswari R et al. Socio-economic impact of tuberculosis on patients and family in India. International journal of tuberculosis and lung disease, 1999, 3(10): 869-77.
12. Timyan $\mathrm{J}$ et al. Access to care: more than a problem of distance. In: Koblinksy M, Timyan J, Gay J, eds. The health of women: a global perspective. Boulder, Colorado, Westview Press, 1993:21734.

13. Rubel AG, Garro LA. Social and cultural factors in the successful control of tuberculosis. Public health reports, 1992, 107:626-36.

14. Grange J, Festenstein F. The human dimension of tuberculosis control. Tubercle and lung disease, 1993, 74(4): 219-22.

15. Westaway MS, Wolmarans L. Cognitive and affective reactions of black urban South Africans towards tuberculosis. Tubercle and lung disease, 1994, 75(6): 447-53.

16. Godin G, Shephard RJ. Physical fitness promotion programs: effectiveness in modifying exercise behaviour. Canadian journal of applied sport sciences, 1983, 8:104-13.

17. Liefooghe $\mathrm{R}$ et al. From their own perspective. A Kenyan community's perception of tuberculosis. Tropical medicine \& international health, 1997, 2(8):809-21.

18. Auer $C$ et al. Health-seeking and perceived causes of tuberculosis among patients in Manila, Philippines. Tropical medicine \& international health, 2000, 5(9):648-56.

19. Nair DM, George A, Chacko K. Tuberculosis in Bombay: new insights from poor urban patients. Health policy and planning, 1997, 12(1):77-85. 